\title{
Erratum to: A New Scale to Measure Executive Servant Leadership: Development, Analysis, and Implications for Research
}

\author{
Lora L. Reed \\ Deborah Vidaver-Cohen \\ Scott R. Colwell
}

\section{Erratum to: Journal of Business Ethics DOI 10.1007/s10551-010-0729-1}

The following material was omitted from the article 'A New Scale to Measure Executive Servant Leadership: Development, Analysis and Implications for Research', published online 13 January 2011.

Notes:

An earlier version of this paper by Vidaver-Cohen, Reed and Colwell was presented in August 2010 at the 70th Annual Meeting of the Academy of Management, Montreal, QC, and was nominated as a Best Paper Finalist by the Social Issues in Management Division. The authors wish to thank the Southern Management Association Research Incubator Program for generous support of this research, as well as Professor Robert C. Liden and Professor Linda Klebe Trevino for helpful comments and suggestions in developing the article.

All three authors contributed equally to this research.

\section{Author Biographies:}

Lora L. Reed, PhD is Assistant Professor of Management at Eckerd College. Her research interests include leadership, followership and organizational citizenship behavior.

The online version of the original article can be found under doi:10.1007/s10551-010-0729-1.
Deborah Vidaver-Cohen, $\mathrm{PhD}$ is Associate Professor of Management at Florida International University College of Business Administration. Her current research focuses on the role of leadership in building strong organizational reputations, creating ethical work climates and managing organizational crises.

Scott R. Colwell, PhD is Associate Professor in the College of Management and Economics at the University of Guelph, Ontario and Adjunct Professor in the University of Guelph's Department of Psychology. Dr. Colwell's research interests center on social issues in management and quantitative methods.

Missing Citation and Reference:

The last paragraph in Column 1 on the second page of the article is amended as follows:

Among the numerous leadership frameworks presented in the management literature, one that articulates the emotional, relational, and moral dimensions of leadership in a particularly useful way is the concept of Servant Leadership, introduced four decades ago by Greenleaf (1970) and currently attracting renewed interest among scholars and managers alike (see Avolio et al., 2009; VidaverCohen et al., 2010).

The following reference was omitted from the article:

Vidaver-Cohen, D., L. L. Reed and S. R. Colwell: 2010, 'Executive Servant Leadership: A New Scale to Test if Leaders Dare to Care', Academy of Management Annual Meeting Proceedings, Montreal, QC, August 6-10, 2010 (Best Paper Finalist, Social Issues in Management Division). 
Lora L. Reed Eckerd College, St. Petersburg, FL, U.S.A. E-mail:ReedLL@eckerd.edu; Lreed7@tampabay.rr.com

Deborah Vidaver-Cohen Florida International University, Miami, FL, U.S.A. E-mail:vidaver@fiu.edu
Scott R. Colwell College of Management and Economics, University of Guelph, Guelph, ON, Canada E-mail:scolwell@uoguelph.ca 